\title{
Penerapan Pendekatan Matematika Realistik Pada Materi Bangun Datar Melalui Kebudayaan Kampung Kuta
}

\author{
Firsta Adilaturrahmah ${ }^{1}$, Suparni ${ }^{2 *}$ \\ ${ }^{1,2}$ Universitas Islam Negeri Sunan Kalijaga, Sleman, D.I. Yogyakarta 55281, Indonesia \\ Pengiriman: 01/Juli/2021; Diterima: 24/September/2021; Publikasi: 31/September/2021 \\ DOI: https://doi.org/10.31629/jg.v6i2.3503
}

\begin{abstract}
Abstrak
Pembelajaran matematika realistik menghubungkan materi pelajaran dengan situasi nyata melalui proses konstruksi pengetahuan yang membuat pembelajaran matematika menjadi lebih bermakna. Artikel ini bertujuan untuk mendeskripsikan proses penerapan pembelajaran matematika dengan pendekatan matematika realistik bebasis kebudayaan Kampung Kuta pada materi geometri pokok bahasan bangun datar. Jenis penelitian ini merupakan penelitian studi kasus dengan pendekatan kualitatif. Subjek dalam penelitian ini adalah siswa MTs AL-Amin Cikaso yang berjumlah 10 siswa. Pengambilan data dilakukan melalui wawancara, observasi, dan dokumentasi. Data yang telah diperoleh selanjutnya dianalisis melalui beberapa tahap, yaitu reduksi data, penyajian data, dan penarikan kesimpulan. Hasil dari penelitian ini menunjukkan bahwa penerapan pendekatan matematika realistik melalui kebudayaan dilakukan melalui beberapa tahap, yaitu memahami masalah kontekstual mengungkapkan ulang gagasan berpikir siswa, menyatakan gagasan tersebut ke dalam suatu gambar, mempresentasikan hasil kerja dan berdiskusi, serta meyimpulkan hasil diskusi mengenai konsep matematika. Model pembelajaran realistik dapat menciptakan suasana belajar yang menyenangkan bagi siswa, menumbuhkan minat dan motivasi siswa, menciptakan pembelajaran yang interaktif, mampu meningkatkan pemahaman siswa melalui permasalahan yang berkaitan dengan kebudayaan Kampung Kuta, serta menumbuhkan sikap cinta dan melestarikan kebudayaan yang ada di Kampung Kuta.
\end{abstract}

Kata kunci: matematika realistik; kebudayaan kampung kuta; bangun datar

\begin{abstract}
Realistic mathematics learning connects subject matter with real situations through a knowledge construction process that makes mathematics learning more meaningful. This article aims to describe the process of applying mathematics learning with a realistic mathematical approach based on the culture of Kampung Kuta on the geometry of the subject of flat shapes. This type of research is a case study research with a qualitative approach. The subjects in this study were students of MTs AL-Amin Cikaso, totaling 10 students. Data were collected through interviews, observation, and documentation. The data that has been obtained is then analyzed through several stages, namely data reduction, data presentation, and drawing conclusions. The results of this study indicate that the application of a realistic mathematical approach through culture is carried out through several stages, namely understanding contextual problems, re-expressing students' thinking ideas, expressing these ideas into a picture, presenting the results of work and discussions, and concluding the results of discussions about mathematical concepts. Realistic learning models can create a pleasant learning atmosphere for students, foster student interest and motivation, create interactive learning, increase students' understanding through problems related to the culture of Kampung Kuta, as well as foster an attitude of love and preserve the existing culture in Kampung Kuta.
\end{abstract}

Keywords: realistic mathematics; culture of kampung kuta; flat shapes

*Penulis Korespondensi

Email Address: suparni@uin-suka.ac.id

Handphone $\quad:+6281575941742$ 


\section{JURNAL GANTANG. September 2021; VI(2): 125 - 132 \\ p-ISSN. 2503-0671 \\ e-ISSN. 2548-5547}

\section{Pendahuluan}

Matematika merupakan ilmu dasar yang sangat erat kaitannya dengan manusia (Tampubolon, 2016). Namun, sampai saat ini matematika masih menjadi mata pelajaran yang banyak tidak disukai dan dianggap sulit untuk dipahami oleh siswa. Anggapan tersebut dapat mempengaruhi cara berpikir siswa dan hasil belajar matematika. Siregar (2017) mengatakan bahwa siswa yang menganggap matematika sulit akan membentuk kesan dan pengalaman yang negatif terhadap matematika, umumnya berdampak buruk bagi motivasi belajar matematika maupun penyesuaian akademik. Kesulitan belajar matematika tidak hanya dipengaruhi oleh persepsi peserta didik saja, namun juga dipengaruhi oleh faktor-faktor lain. Menurut Ramli (2013) faktor kesulitan belajar matematika melibatkan apresiasi terhadap struktur matematika, ketersediaan sumber belajar, kualitas guru, kurikulum, peserta didik itu sendiri, dan nilai masyarakat terhadap matematika.

Penguasaan teknik pedagogik guru sangat penting dilakukan, karena proses penyampaian materi matematika dari guru kepada siswa akan membantu siswa memahami konsep matematika. Menurut Tampubolon (2016), guru tidak hanya bertugas menyampaikan dan mengajarkan matematika yang abstrak secara langsung kepada siswa, namun guru seyogyanya dapat memfalsilitasi siswa dengan menyajikan pembelajaran secara konkret sehingga mereka dapat memahami konsep matematika secara nyata serta pembelajaran matematika menjadi menyenangkan dan bermakna. Dengan demikian, guru harus mampu memilih metode yang tepat dalam menyampaikan konsep matematika yang abstrak, sehingga siswa dapat memahami konsep tersebut dan pembelajaran matematika dapat lebih bermakna.

Matematika pada hakikatnya sebagai aktivitas manusia tentu sangat berkaitan dengan kegiatan manusia dalam sehari-hari. Tidak bisa dipungkiri bahwa hampir setiap waktu manusia melakukan aktivitas yang mengandung konsep matematika. Konsep matematika yang dikaitkan dengan kegiatan sehari-hari akan mudah dipahami oleh siswa. Irawan (2017) mengatakan bahwa siswa menjadi lebih tertarik dan bersemangat dalam mempelajari matematika dengan berbagai macam contoh nyata dalam kehidupan sehari-hari sehingga konsep matematika yang abstrak menjadi lebih konkrit. Proses pembelajaran tersebut dapat menjadi terobosan baru bagi guru dalam menyampaikan materi matematika yang abstrak, salah satunya pembelajaran matematika dengan pendekatan realistik.

Pendekatan matematika realistik merupakan pendekatan pembelajaran yang menghubungkan materi pelajaran dengan situasi nyata yang dikenal siswa serta proses konstruksi pengetahuan matematika oleh siswa sendiri (Yusmanita, S., Ikhsan, M., \& Zubainur, C. M., 2018). Ahmad (2018) menjelaskan bahwa pembelajaran dengan pendekatan matematika realistik senantiasa berangkat dari dunia nyata ke dunia bahasa matematika dan dilanjutkan dengan menerapkan konsep tersebut dalam pemecahan permasalahan kehidupan sehari-hari serta mampu membuat pembelajaran lebih bermakna.

Makna real pada matematika realistik tidak hanya situasi yang nyata dan nampak oleh manusia, tetapi juga merupakan suatu khayalan yang dapat dibayangkan oleh pikiran manusia. Sesuai dengan pernyataan Ningsih (2014) bahwa pendekatan matematika realistik harus mempunyai keterkaitan dengan situasi nyata yang mudah dipahami dan dibayangkan oleh siswa sehingga dapat meningkatkan struktur pemahaman matematika siswa.

Matematika realistik memiliki karakteristik yang sangat erat kaitannya dengan aktivitas manusia, sehingga pembelajaran ini melatih siswa untuk berperan aktif sebagai subjek belajar serta memberi kesempatan kepada siswa untuk menemukan ide dan konsep matematika sendiri. Menurut Badruddin (2013) dalam pendekatan matematika realistik siswa dipandang sebagai individu (subjek) yang memiliki potensi untuk mengembangkan sendiri pengetahuan dan pemahaman mereka mengenai matematika. Dalam pembelajaran matematika realistik, siswa 
mengembangkan sendiri pengetahuannya secara mandiri atau berkelompok untuk menyelesaikan permasalahan kontekstual matematika dengan strategi atau cara penyelesaian yang diciptakan sendiri. Peran guru dalam hal ini sebagai fasilitator siswa yang membimbing para siswa untuk menemukan konsep matematika sendiri.

Pembelajaran matematika realistik memiliki karakteristik yang utama, yaitu penggunaan masalah kontekstual dalam pembelajaran. Febriani, P., Widada, W., \& Herawaty, D. (2019) menjelaskan bahwa penerapan matematika realistik melalui budaya artinya pembelajaran matematika yang diberikan dimodifikasi sesuai dengan adat, istiadat serta budaya masyarakat setempat dimana sekolah tersebut berada. Lebih lanjut, Febriani et al., (2019) menjelaskan bahwa penggunaan kontekstual yang dimodifikasi dengan unsur budaya dapat menjembatani pembelajaran matematika, atau yang lebih dikenal dengan etnomatematika.

Penerapan pembelajaran matematika realistik yang berbasis kebudayaan memberikan dampak positif bagi para siswa. Hal ini terbukti berdasarkan beberapa hasil penelitian yang menyatakan bahwa pembelajaran matematika realistik dapat meningkatkan hasil belajar siswa. Novrianto, A., Maryuni, N., \& Amri M.A (2017) dalam penelitiannya mengenai pengaruh pendekatan matematika realistik terhadap komunikasi matematis siswa, menjelaskan bahwa pembelajaran yang menggunakan pendekatan matematika realistik mampu meningkatkan kemampuan komunikasi matematis siswa. Melisa, Widada, W., \& Zamzaili. (2019) melaksanakan penelitian mengenai pembelajaran matematika realistik berbasis etnomatematika Bengkulu, dan menunjukkan bahwa pembelajaran tersebut dapat meningkatkan kognisi matematis siswa.

Indonesia memiliki beragam kebudayaan yang memiliki keunikan masing-masing dan dapat digunakan dalam pembelajaran matematika. Salah satu kebudayaan di Jawa Barat yang memiliki keunikan dan erat kaitannya dengan matematika adalah kebudayaan di Kampung
Kuta. Kampung ini terletak di pesisir Jawa Barat yang beratasan dengan Provinsi Jawa Tengah, tepatnya berada di Desa Karangpaningal, Kecamatan Tambaksari, Kabupaten Ciamis. Adat Istiadat dan kepercayan masyarakat Kampung Kuta masih sangat kuat, termasuk dalam hal tata letak dan pembuatan bangunan. Kusmayadi, E., Nurohman, T., Satori, A., \& Widiastuti, W. (2010) menyatakan bahwa dalam mendirikan rumah harus memperhatikan arah dan tata letak rumah yang akan dibangun. Terdapat larangan ketika hendak memperbaiki atau menambah bagian rumah, yakni tidak boleh menambah rumah ke arah timur dan utara. Larangan tersebut dilakukan dengan tujuan agar masyarakat Kampung Kuta senantiasa hidup tentram serta terhindar dari bahaya dan segala bentuk kejahatan.

Disamping aturan dan larangan dalam mendirikan rumah, rumah adat kampung kuta memiliki keunikan dalam bentuk bangunan rumahnya dan mengandung konsep geometri pada matematika. Intani (2013) menjelaskan bahwa rumah adat Kampung Kuta berbentuk panggung dengan atap rumah menyerupai trapesium yang terbuat dari rumbia atau ijuk serta dinding rumah berbentuk persegi panjang dan bentuk rumah tidak boleh menyiku. Rumahrumah di Kampung Kuta berjajar di tepi jalan kampung atau mengelompok pada tanah yang datar. Kelompok rumah yang satu dengan lainnya berjauhan. Setiap rumah berpekarangan luas dengan tanaman pokoknya kawung. Bentuk rumah adat Kampung Kuta tersebut mengandung konsep matematika pada materi geometri yang dapat digunakan dalam pembelajaran matematika.

Berdasarkan uraian tersebut, peneliti tertarik untuk melakukan penelitian mengenai penerapan pendekatan matematika realistik pada materi geometri melalui kebudayaan Kampung Kuta. Tujuan dari penelitian ini adalah untuk mengetahui bagaimana kebudayaan Kampung Kuta dapat digunakan untuk pembelajaran matematika dengan pendekatan matematika realistik. Selain itu, penelitian ini dilakukan untuk 


\section{JURNAL GANTANG. September 2021; VI(2): 125 - 132 \\ p-ISSN. 2503-0671 \\ e-ISSN. 2548-5547}

mengekplorasi salah satu kebudayaan Jawa Barat yaitu Kampung Kuta yang belum banyak diketahui oleh masyarakat Indonesia. Melalui penelitian ini, peneliti berharap masyarakat bisa lebih peduli terhadap keberagaman budaya Indonesia, dan bagi guru dapat menciptakan kegiatan pembelajaran yang lebih bermakna, salah satunya dengan pendekatan matematika realistik melalui kebudayaan Kampung Kuta.

\section{Metode Penelitian}

Penelitian ini merupakan penelitian studi kasus deskriptif kualitatif yang bertujuan untuk mendeskripsikan penerapan matematika realistik melalui kebudayaan Kampung Kuta, pada materi geometri pada pokok bahasan bangun datar. Penelitian studi kasus merupakan penelitian yang mengeksplorasi permasalahan yang memiliki batasan tertentu, pengambilan data yan mendalam dan menyertakan informasi yang diperoleh dari berbagai sumber (Rangkuti, 2016). Penelitian dilaksanakan di salah satu sekolah swasta yang berada di kabupaten Ciamis, yaitu di MTs AlAmin Cikaso. Subjek penelitian adalah siswa kelas VII MTs Al-Amin Cikaso Tahun Pelajaran 2020/2021 yang berjumlah 10 orang. Pemilihan subjek penelitian dilakukan berdasarkan objek dan tujuan penelitian, yakni penerapan pembelajaran matematika realistik pada materi geometi pokok bahasan bangun datar.

Teknik pengumpulan data dilakukan dengan wawancara, observasi, dan dokumentasi. Wawancara dilaksanakan secara mendalam kepada subjek penelitian untuk memperoleh data secara jelas dan lengkap. Obsevasi dilaksanakan selama proses pembelajaran berlangsung dan ketika wawancara dilaksanakan. Dokumentasi digunakan untuk melengkapi data yang dibutuhkan dan memperjelas data yang telah diperoleh.

Analisis data dilakukan meliputi reduksi data, penyajian data, dan penarikan kesimpulan. Reduksi data merupakan teknik memilih dan merangkum hal-hal pokok untuk difokuskan kepada tema dan hal-hal yang penting (Sugiyono, 2017). Data yang telah direduksi dilakukan uji validitas melalui metode triangulasi untuk memeriksa kembali data yang diperoleh agar meningkatkan keabsahan data. Selanjutnya data disajikan dalam bentuk tulisan yang terorganisasi dan memungkinkan untuk melakukan penarikan kesimpulan (Ahmad, 2018). Langkah terakhir adalah penarikan kesimpulan berdasarkan data yang telah dianalisis dari data yang diperoleh melalui wawancara dan observasi. Penarikan kesimpulan dilakukan secara deskriptif mengenai penerapan pendekatan matematika realistik melalui kebudayaan Kampung Kuta pada pokok bahasan bangun datar.

\section{Hasil dan Pembahasan}

Penerapan pembelajaran matematika realistik yang dilaksanakan di MTs Al-Amin cikaso terdiri dari lima tahap berdasarkan langkah-langkah pembelajaran matematika realistik. Syamaun (2010) menjelaskan langkah-langkah dalam pembelajaran yang menggunakan pendekatan matematika realistik diantaranya adalah (1) memahami masalah kontekstual; (2) menjelaskan masalah kontekstual; (3) menyelesaikan masalah kontekstual; (4) membandingkan dan mendiskusikan jawaban; serta (5) menyimpulkan.

Kegiatan awal penerapan pendekatan matematika realistik kepada siswa MTs Al-Amin Cikaso dengan kebudayaan Kampung Kuta, guru memberikan pengantar berupa informasi mengenai kebudayaan Kampung Kuta. Berdasarkan hasil wawancara dan pengamatan ketika pembelajaran berlangsung, para siswa terlihat masih asing dengan nama kampung tersebut. Sebagian siswa mengaku pernah mendengar, namun tidak mengetahui dengan jelas keberadaan Kampung Kuta. Setelah guru menjelaskan dan memberikan sedikit gambaran mengenai kebudayaan tersebut, para siswa terlihat tertarik dengan tema yang sedang dibahas. Para siswa nampak antusias ketika menjawab pertanyaan mengenai informasi Kampung Kuta yang telah diberikan sebelumnya. Selanjutnya guru mengarahkan siswa untuk memfokuskan pembelajaran matematika realistik melalui keunikan bentuk rumah adat Kampung Kuta. 


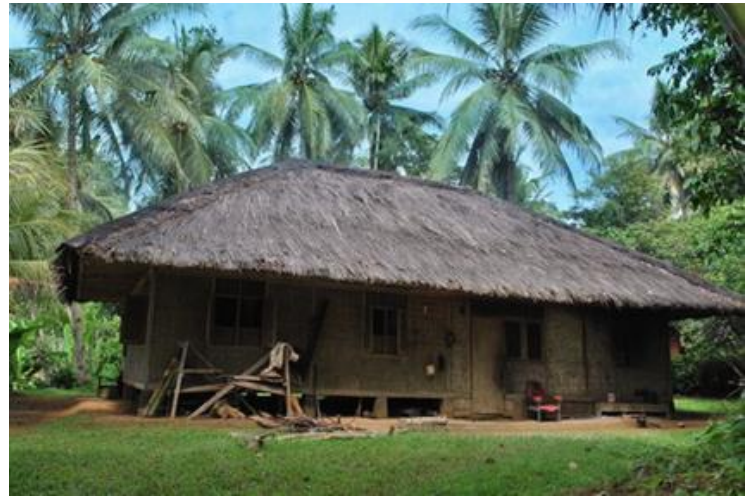

Gambar 1. Rumah adat kampung kuta

Langkah pertama pada kegiatan pembelajaran matematika realistik melalui rumah adat kuta adalah para siswa memahami masalah kontekstual yang terdapat pada rumah adat tersebut. Berdasarkan gambar diatas, terlihat bahwa rumah adat ini memiliki keunikan dan mengandung konsep geometri yang dapat diklasifikasikan ke dalam bentuk bangun datar dan bangun ruang. Para siswa diberi kebebasan untuk menentukan dan mengklasifikasikan bentuk bangun datar yang ada pada rumah adat Kampung Kuta. Kegiatan ini bertujuan agar siswa dapat lebih mengenal kebudayaan Indonesia, khususnya kebudayaan daerah setempat dan dapat mempelajari konsep matematika yang ada di dalamnya.

Setelah memahami masalah konteksual, guru mengarahkan siswa untuk menyampaikan gagasan atau hasil berpikirnya kepada siswa yang lain. Hal ini dilakukan untuk mengetahui kemampuan siswa dalam menyampaikan dan menjelaskan masalah kontekstual yang telah mereka pahami. Berdasarkan hasil penyampaian mereka, terdapat perbedaan hasil antara siswa yang satu dengan yang lainnya mengenai bentukbentuk bangun datar yang terdapat pada rumah adat kampung kuta. Perbedaan tersebut memberikan makna bahwa setiap siswa memiliki pendapat dan pemikiran sendiri yang tidak harus sama dengan yang lainnya. Sehingga, siswa dapat dengan bebas memahami setiap masalah matematika yang ditemukan.

Langkah selanjutnya adalah guru membimbing siswa untuk menyatakan gagasannya tersebut ke dalam suatu gambar atau sketsa bangun datar yang telah ditemukan oleh masing-masing siswa. Para siswa juga harus menyertakan karakteristik atau sifat yang terdapat pada setiap bangun datar yang telah ditemukan. Berdasarkan tinjauan dari hasil kemampuan siswa dalam menyatakan masalah, siswa dapat memahami permasalahan dengan baik dan dapat menyatakan masalah kontekstual pada kehidupan sehari-hari ke dalam bahasa atau model matematika.

Setelah seluruh siswa berhasil menuangkan pemahamannya pada sebuah gambar, salah seorang siswa menyampaikan hasil pengerjaannya kemudian siswa lainnya mencermati dan membandingkan jawaban yang dimilikinya dengan teman yang lain. Para siswa dibimbing untuk mendiskusikan jawaban mereka dengan perbandingan yang telah mereka temukan. Jawaban yang diperoleh oleh setiap siswa tidak sama, karena penyelesaian dari permasalahan matematika tidak hanya memiliki satu jawaban saja, melainkan terdapat beragam cara penyelesaian yang kemudian perbedaan tersebut dapat disimpulkan bersama dengan solusi terakhir yang sama. Irawan \& Kencanawati (2017) menjelaskan bahwa perbedaan cara menjawab permasalahan matematika menjadikan kemampuan siswa yang lebih variatif dalam menelaah soal yang disajikan dalam bentuk evaluasi pembelajaran matematika.

Langkah terakhir pada pembelajaran matematika realistik melalui rumah adat kampung kuta adalah meyimpulkan hasil diskusi dari para siswa. Berdasarkan hasil diskusi sebelumnya, guru bersama siswa menyimpulkan dan mengklasifikasikan bentuk-bentuk bangun datar berdasarkan jumlah sisinya. Pada rumah adat Kampung Kuta, terdapat bangun datar segitiga dan segi empat yang terdiri dari persegi panjang, dan trapesium. Segitiga dan trapesium terletak pada atap rumah, sedangkan persegi panjang terletak pada tubuh rumah. Selain karakteristik berdasarkan jumlah sisinya, bangun datar tersebut juga memiliki karakteristik lain berdasarkan sudut, diagonal, dan lainnya yang dapat 


\section{JURNAL GANTANG. September 2021; VI(2): 125 - 132 \\ p-ISSN. 2503-0671 \\ e-ISSN. 2548-5547}

disimpulkan bersama berdasarkan hasil diskusi siswa.

Selain rumah adat Kampung Kuta, konsep matematika juga terdapat pada sistem mata pencaharian yang dilakukan oleh masyarakat kampung kuta. Rosyadi, E., \& Tim Penulis (2014) menjelaskan bahwa mata pencaharian utama masyarakat Kampung Kuta adalah bertani dengan sistem dan peralatan pertanian yang tradisional. Sebagian besar masyarakat Kampung Kuta bermata pencaharian sebagai petani, baik petani pemilik maupun petani penggarap.



Gambar 2. Lahan pertanian masyarakat kampung kuta

Jika diperhatikan lebih dalam pada gambar tersebut, cara bercocok tanam masyarakat Kampung Kuta dalam menanam padi mengikuti pola yang menyerupai bentuk persegi dengan jarak yang sama antara satu pohon padi dengan yang lainnya. Bentuk pola yang unik tersebut mengandung konsep matematika yang dapat digunakan dalam pembelajaran matematika realistik. Dengan jarak yang sama pada setiap pohon yang ditanam, maka dapat dihitung luas satu petak sawah yang digarap oleh salah satu warga Kampung Kuta. Konteks demikian akan menjadi lebih menarik bagi siswa karena siswa dapat belajar lebih nyata dari kehidupan seharihari yang mudah ditemukan oleh siswa.

Melalui tahap pembelajaran yang sama pada pembelajaran sebelumnya, siswa dapat memahami dengan baik masalah kontekstual pada cara bercocok tanam masyarakat Kampung Kuta. Mereka aktif berdiskusi untuk menyelesaikan permasalahan matematika yang ditemukan. Setelah selesai berdiskusi, siswa dan guru dapat menyimpulkan konsep matematika pada lahan pertanian masyarakat Kampung Kuta mengenai luas suatu bangun datar.

Proses pembelajaran matematika yang berbasis kebudayan dapat menciptakan suasana pembelajaran yang menyenangkan bagi siswa. Siswa tidak lagi memandang matematika sebagai ilmu yang menakutkan dan sulit dipahami. Keaktifan siswa berkembang seiring dengan pola berpikir kritis yang muncul ketika memahami dan menyelesaikan permasalahan kontekstual dari kehidupan sehari-hari. Di samping itu, siswa juga dapat memahami unsur matematika yang terdapat dalam kebudayaan sekitar, khususnya budaya di Kampung Kuta. Sehingga siswa akan mendapat pengetahuan mengenai konsep matematika dan pengetahuan mengenai kebudayaan Kampung Kuta.

\section{Kesimpulan}

Pembelajaran matematika realistik yang dilaksanakan melalui kebudayaan memiliki daya tarik sendiri bagi siswa. Pembelajaran matematika dengan pendekatan realistik dilakukan melalui beberapa tahap, yaitu memahami masalah kontekstual yang terdapat pada rumah adat, mengungkapkan ulang gagasan atau hasil berpikir siswa melalui, menyatakan gagasan tersebut ke dalam suatu gambar, mempresentasikan hasil kerja dan berdiskusi, serta meyimpulkan hasil diskusi mengenai konsep matematika.

Proses pembelajaran ini mengembangkan kreativitas dan keaktifan siswa sehingga pembelajaran di kelas menjadi lebih interaktif. Siswa-siswi dapat lebih memahami permasalahan matematika yang berasal dari kehidupan seharihari karena lebih terasa nyata bagi siswa. Model pembelajaran yang demikian dapat menjadi alternatif bagi guru dalam menyampaikan konsep matematika kepada siswa dan menciptakan pembelajaran yang lebih bermakna. Pembelajaran matematika dengan kebudayaan salah satunya dapat dilaksanakan melalui kebudayaan yang berada di Jawa Barat yaitu Kebudayaan Kampung Kuta yang megandung banyak unsur matematika di dalamnya. Dengan pembelajaran matematika 
realistic melalui kebudayan kampong Kuta, siswa diharapkan dapat mengetahui dan melestarikan kebudayaan sekitar yang berada di Kabupaten Ciamis.

\section{Ucapan Terimakasih}

Penulis mengucapkan terima kasih kepada Bapak Kepala Sekolah MTs Al-Amin Cikaso, seluruh dewan guru dan para siswa yang telah memberikan kesempatan kepada penulis untuk melakukan penelitian ini. Peneliti mengucapkan terima kasih khususnya kepada Bapak guru mata pelajaran matematika dan siswa kelas VII MTs Al-Amin Cikaso Tahun Pelajaran 2020/2021 yang telah berperan aktif dalam penerapan pembelajaran dengan pendekatan matematika realistik melalui kebudayaan Kampung Kuta. Ucapan terima kasih peneliti sampaikan kepada Ibu Suparni, S.Pd., M.Pd., selaku dosen yang telah membimbing peneliti dalam melakukan penelitian dan penyusunan artikel ini.

\section{Referensi}

Ahmad, M., \& Nasution, D.P. (2018). Analisis kualitatif kemampuan komunikasi matematis siswa yang diberi pembelajaran matematika realistik. Jurnal Gantang, 3(2), 83-95.

Badruddin, E. (2013). implementasi pendekatan realistik pada pembelajaran operasi bilangan real untuk meningkatkan hasil belajar siswa SMK Negeri 5 Telkom Banda Aceh. Jurnal Peluang, 2(1).

Febriani, P., Widada, W., \& Herawaty, D. (2019). Pengaruh pembelajaran matematika realistik berbasis etnomatematika terhadap kemampuan pemahaman konsep matematika siswa SMA Kota Bengkulu. Jurnal Pendidikan Matematika Raflesia, 4(2), 120-135.

Irawan, A., \& Kencanawaty, G. (2017) Implementasi pembelajaran matematika realistik berbasis etnomatematika. Journal of Medives, 1(2), 74-81.

Kusmayadi, E., Nurohman, T., Satori, A., \& Widiastuti, W. (2010). Tinjauan sosial budaya dan politik masyarakat kampung kuta desa karangpaningal kecamatan

Tambaksari Kabupaten Ciamis.

Tasikmalaya: Fakultas Ilmu Sosial dan Ilmu Politik Universitas Siliwangi.

Melisa, Widada, W., \& Zamzaili. (2019). Pembelajaran matematika realistik berbasis etnomatematika bengkulu untuk meningkatkan kognisi matematis. Jurnal Pendidikan Matematika Raflesia, 4(2), 103-110.

Ningsih, S. (2014). Realistic mathematics education: Model alternatif pembelajaran matematika sekolah. Jurnal Pendidikan matematika IAIN Antasari, 1(2), 73-94.

Novrianto, A., Maryuni, N., \& Amri M.A. (2017). Komunikasi matematis siswa: pengaruh pendekatan matematika realistik. Jurnal Gantang, 2(2), 113-121.

Ramli, F., Shafie, N., \& Tarmizi, R.A. (2013). Exploring student's in-depth learning difficulties in mathematics through teacher's perspective. Procedia - Social and Behavioral Sciences. 97 (2013), 339345 .

Rangkuti, A. N. (2016). metode penelitian pendidikan pendekatan kuantitatif, kualitatif, PTK dan penelitian pengembangan. Bandung : Cipta Pustaka Mulia

Rosyadi, E., \& Tim Penulis. (2014). Kajian kearifan lokal di kampung Kuta Kabupaten Ciamis. Bandung: Izda Prima, CV.

Siregar, N. R. (2017). Persepsi siswa pada pelajaran matematika: Studi pendahuluan pada siswa yang menyenangi game. Prosiding Temu Ilmiah X Ikatan Psikologi Perkembangan Indonesia.

Sugiyono. (2017). Metode penelitian kuantitatif, kualitatif, dan $R \& D$. Bandung: Alfabeta, CV.

Syauman, Muzakkir. (2010). Pendekatan matematika realistik cara efektif meningkatkan pemahaman logika matematika siswa. Banda Aceh: SepNas FKIP UNSYIAH, 24-25 Juni 2010.

Tampubolon, P. T. (2016). penerapan model 
JURNAL GANTANG. September 2021; VI(2): 125 - 132

p-ISSN. 2503-0671

e-ISSN. 2548-5547

pembelajaran matematika realistik

indonesia untuk meningkatkan aktivitas

dan hasil belajar siswa kelas IV SD. Jurnal

Pendidikan Guru Sekolah Dasar. 1(1), 190-198.

Yusmanita, S., Ikhsan, M., \& Zubainur, C. M.

(2018). penerapan pendekatan matematika realistik untuk meningkatkan kemampuan operasi hitung perkalian. Jurnal Elemen, 4(1) : 93-104. 